\title{
THE INFLUENCE OF COMMUNICATION ON THE PURCHASE OF GIFTS ON COMMEMORATIVE DATES
}

\author{
Flávia N. Mantovani Alves ${ }^{1}$, Luciana Florêncio de Almeida ${ }^{1}$ and Eduardo Eugênio Spers ${ }^{2}$ \\ ${ }^{I}$ ESPM - Escola Superior de Propaganda e Marketing, Brazil \\ ${ }^{2}$ University of São Paulo (USP), Brazil
}

\begin{abstract}
The research evaluates different attributes explored by communication that may influence the choice of gift by the consumer (Gift Giving), in this case, in the category of Panettones (seasonal product, present only in the Brazilian's Christmas) during Christmas. Using tools such as eye tracking, it is possible to identify the effectiveness of the advertising message to the consumer, especially in seasonal seasons (commemorative dates), where the flow of advertising messages is very high. The commemorative date market allows retailers to incrementally grow and stream more consumers and make individuals consume and give more naturally. Christmas is considered to be the main of these retail commemorative dates. Understanding this relationship of choosing a brand as a gift is the subject of this dissertation. Among the managerial and academic contributions is the enrichment of studies that correlate the importance of investment in communication campaigns in seasonal periods (commemorative dates), allowing to identify elements for actions that generate a closer relationship between target audience and advertiser, as well as understand What are the factors that can increase purchase intent at the moment of choosing one, approaching and reinforcing consumer identification. The object of study chosen for the empirical test is the Panettones category. Research will be conducted with potential consumers of this product through the use of eye tracking equipment to analyze the product present in different scenarios with different elements in order to understand what is most appealing in a panettone advertising piece. The literature review is based on gift giving, seasonal periods and how important they are to retailers - focusing on Christmas.
\end{abstract}

\section{KEYWORDS}

Gift Giving, Eye Tracking, Commemorative Dates, Christmas, Communication, Emotion

\section{INTRODUCTION}

Investment in communication is a reality in the advertising world. And with so many messages and ads running at the same time, the importance of creating relevant, conversational communications with the public is enormous.

According to Schiffman and Kanuk (2009), to get the attention of consumers, companies need to know their habits, as well as the personal and social factors that can influence decision making at the time of purchase. This information is crucial to direct the elaboration of the advertising message effectively addressed to the target audience.

The commemorative dates contribute to the retail economic movement, as they generate incremental volume within the stores and also a greater flow of consumption during these periods. People are willing to spend more and therefore brands invest more of their advertising dollars during these periods. And, among the commemorative dates, Christmas is still the main one and where the largest sales volume is concentrated.

Christmas is considered, beyond a date, a ritual that is still celebrated all year around the world, even in places where there are no Christian traditions (Pinto, 2014). In the West, for example, the party involves rituals such as family parties, the exchange of gifts between loved ones, decorations, sending messages, among others.

Santana (2013) states that, driven by the Brazilian capitalist economy, consumers are impacted by advertisements with an appeal to consumption "disguised" with positive symbols and meanings that have to do with the date - peace, unity, family and festivity. The stimulus that the date represents for the Brazilian economy 
in various product segments are surrounded by advertising messages that have strong visual and aesthetic appeal with symbols of the period (Christmas tree, Santa Claus, etc.), very focused on the act of give away.

Gift giving is a sociocultural phenomenon. During commemorative dates, the act intensifies and this has been increasingly explored by brands and their communications, especially through messages that appeal to the emotion.

In a consultation conducted at the Web of Science database, using the term Gift Giving and Christmas, for the period between 1959 and 2019, only 46 records were found. In other words, despite being a subject of interest to the economy and the brands that operate on commemorative dates, with Christmas being the main of these dates, the systematic review carried out showed little attention from the researchers on this subject.

As a way to add to existing studies on gift giving and specifically on commemorative dates, the paper seeks to answer the following questions: How can gift giving at Christmas be affected by communication attributes (text / message, packaging, emotion (based on affection) and nostalgia)? The object of study chosen for empirical research is one of the Brazilian icons of Christmas, Panettone.

\section{LITERATURE REVIEW}

The literature review chapter brings concepts and theories already developed by national and international literature about topics relevant to the work, including the concepts of gift giving, seasonality and its influence on consumption - focusing on the main date. Commemorative of the year, Christmas.

\subsection{Gift Giving}

What drives people to give to others is the desire to maintain interpersonal relationships, materializing them in some way. The act of gifting also carries the identity of the gift giver as well as the gift giver, since it seeks to assign meaning to the gift in question, which primarily aims to please the gift recipient (Klein, 2015). The purchase of gifts does not only involve the act of purchasing the product or service, but carries a whole symbolism and meaning - influenced by the sociocultural baggage of the buyer (Pécepe, 2002).

Gifts are exchanged mainly between friends and family, since the gift giving is directly linked by the degree of connection between people. Consumers often give gifts to others who have a high emotional and sentimental connection (Belk, 1979).

Gift giving is a sociocultural phenomenon of contemporary society. On commemorative dates, the movement of commerce increases too much, as do the profits of retailers - precisely because of this movement in search of gifts.

Utilizing the "emotion" factor can benefit sales as a whole on holiday dates as it generates consumer identification and helps build special meaning around the present (Taute and Sierra, 2015).

The more the brand understands what people expect to receive for what is offered, the more effective is the message built into their campaigns. And that's no different when it comes to seasonal periods, when choosing gifts - even more so when excitement is at stake.

It is extremely important for brands to focus on messages that create identification and generate emotion with their target audience, to build a good relationship and future consumer loyalty.

\subsection{The Role of Packaging in the Purchase Decision Process}

Product packaging that previously had the role of protecting it from external interference, transporting or storing it, has become more important over time, especially as consumer demand and retail demand increase. (Oliveira, 2018).

According to Kotler (2000), packaging should be seen as a powerful weapon in favor of brands, as it becomes the first physical contact between the product and the consumer within the points of sale, helping to awaken the consumer's desire to buy.

Packaging can appeal to consumers and drive their purchasing decision by combining appearance and functionality that they deliver to the product in question.

Gift packaging is already expected when a consumer looks for a Christmas gift. It can be said to be a congruent element to date and, in turn, characterizes the product as a gift item. 
Based on what was explored in this literature review chapter, the following hypothesis will be tested:

H1: The presence of a giftable packaging in an advertisement increases the intention to gift (more than a non-giftable packaging or no packaging).

\subsection{Consumption Seasonality and the Price Factor}

Some times of the year are considered seasonal times, mainly for retail, precisely because they provide an increase in retail demand. This is the case, for example, of Christmas, Mother's and Father's Day, Valentine's Day and so on.

These dates, according to some experts, are seen as strategic for retail companies, as they encourage consumers to increasingly consume for themselves and specially to give gifts to loved ones.

According to France (2019), on commemorative dates, individuals consume and give, increasing their spending that may even lead them to a debt process, since they are more able to spend more when choosing a gift. However, in the midst of an unstable economic environment, consumers still prefer to choose options that have a perceived cost-benefit - price is an important factor, even though they are willing to spend more on holiday season, they still prefer to have cheaper options on the market. moment of choice, according to the type of gift and the person to be gifted.

Based on what was explored in this literature review chapter, the following hypothesis will be tested:

$\mathrm{H} 2$ : Price is a factor that influences the choice of gift.

\subsection{The Use of Nostalgia in Advertising}

Christmas as a celebration date is considered an important Christian religious holiday. Nonetheless, the "non-Christian" world is also impacted by the date, which has gained significance thanks to American influence and the icon of Santa Claus. However, despite being loaded with symbols and meanings, it is also the most lucrative and important retail date, even in countries where Christianity is not the predominant religion (Belk, 1987).

Particularly in times of crisis - financial or political - brands seek, through marketing strategies, to reassure consumers through their campaigns using nostalgia, to make people feel safer and more secure (Boyle, 2009).

In a broader definition one has that personal nostalgia is "a positively valued complex feeling, emotion or mood produced by reflection on the things (objects, people, ideas) associated with the past." (Holak and Havlena, 1998, p. 218). From this it is concluded that "it is possible to remember without being nostalgic, but one cannot be nostalgic without remembering" (Batcho, 2007, p. 362).

When it comes to commercials served during seasonal periods - that is, they relate directly to specific times of the year, such as Christmas - so that the brand makes it easy to identify in the consumer's mind, these ads often exploit socially pre-established signs that mention the date, such as decorations, Christmas tree, supper, flashers and so on. All this makes up what can be called the Christmas atmosphere - elements that are often used in advertising for consumers to recognize the time of year being portrayed and that can also be treated as nostalgic elements, for creating a memory between consumer and Christmas. Such elements may be used in favor of the mark by advertising.

Based on what was explored in this session, the following assumptions will be tested:

H3a: The presence of an emotion-related attribute - based on the representation of affect - increases the intention to gift;

$\mathrm{H} 3 \mathrm{~b}$ : The presence of a text based on emotion increases the intention to give;

H4: The choice of nostalgic elements, such as the representation of the Christmas tree, increases the intention to give away.

\section{HYPOTHESES AND METHODOLOGY}

Christmas, because of its importance for the seasonality of the market, ends up being the focus of communication investments over the years, and is characterized by being associated with nostalgic elements and the transmission of positive emotions. All of this affects consumer perception and choice of the brand / product in question at the time of purchase. 
For the construction of communication, several attributes are taken into consideration - which may further influence the choice of a particular brand / product when choosing a gift.

Not least, it is important to note that donor identification with the gift to be chosen is very much taken into consideration - it serves as a great motivator and reinforcement of that choice.

The study seeks to investigate the interference of communication attributes in the act of giving and how it affects the moment of choice of brand / product. For this, the following hypotheses to be tested are as follows:

H1: The presence of a giftable packaging in an advertisement increases the intention to gift (more than a non-giftable packaging or no packaging).

$\mathrm{H} 2$ : Price is a factor that influences the choice of gift.

H3a: The presence of an emotion-related attribute - based on the representation of affect between people increases the intention to give;

$\mathrm{H} 3 \mathrm{~b}$ : The presence of a text based on emotion increases the intention to give;

H4: The choice of nostalgic elements, such as the representation of the Christmas tree, increases the intention to give away.

The study aimed to investigate the interference of communication attributes in the act of giving and how much it affects when choosing the brand / product. Therefore, we chose to use eye tracking technology to collect information about volunteer survey respondents.

Eye Tracking, according to Barreto (2012, p. 168), consists of a "set of technologies that allow measuring and recording the eye movements of an individual when sampling a stimulus". The tool is able to tell in which areas and for how long the consumer keeps their attention while watching the ad in question, through fixation volume measurements and visual behavior patterns.

The collection was made with 16 master students from the School of Advertising and Marketing (ESPM). The study was done in a laboratory, in a controlled environment and the sample was chosen for convenience.

The students, one by one, were placed in front of a computer screen in order to analyze some advertisements in Panettones banner formats (product that only exists at Christmas time in Brazil).

The ads were structured as follows:

1. A table was set up with four different attributes to be evaluated (scenario, product, price and message);

2. Three situations were created for each attribute, aiming to set up different situations and with different weights of each chosen attribute:

a. Scenario:

i. With Christmas elements;

ii. With Christmas elements and people (family);

b. Product:

iii. No Christmas elements;

i. With common packaging;

ii. With gift packaging;

iii. Without packaging; category):

c. Price (the values were chosen according to what the retailer stands in relation to the panettone

i. R \$ 24.99;

ii. $\mathrm{R} \$ 29.99$;

iii. R \$ 34.99;

d. Message:

i. Gift your family members;

ii. Give your co-workers a gift;

iii. Promotional message (buy Panettone).

The previous list of factors and situations was used as the basis for generating possible combinations in Tobii Pro Studio software. Of all possible combinations, the program listed 18 main combinations, which were structured into banner advertising forms and presented to students, two by two, under eye tracking evaluation. In addition to asking about the preference between the two ads shown at a time, their visual attention was also assessed as they analyzed the pieces. 


\section{RESULTS AND CONCLUSION}

By combining preference responses between ads, a new analysis was generated within the Tobii Pro Studio software, which yielded the following results:

1) Gift packaging increases the probability of product choice by $16.2 \%$;

2) The scenario with Christmas increases by $11.6 \%$ the probability of choosing the product;

3 ) Ordinary packaging increases the probability of product choice by $11.4 \%$, and;

4) The message about family increases by $9.2 \%$ the probability of choosing the product.

Along with these responses, we analyzed the heat maps generated by the eye tracking equipment (to understand respondents' eye movement as well as their focus of attention on the ads). Thus, it was possible to complement the answers as follows:

1) Gift packaging increases the likelihood of product choice by $16.2 \%$ : Heat maps also show that gift packaging, when compared to traditional or unpackaged packaging, forms denser clouds of heat., which means they get more attention within the ad;

2) The scenario with Christmas increases the probability of choosing the product by $11.6 \%$ : we can observe that the presence of the Christmas scenario (Christmas tree) at the bottom of the ads ends up distributing the attention of the consumer (who, when they do not find the tree, end up focusing too much on the text);

3) Ordinary packaging increases the probability of product choice by $11.4 \%$ : in heat maps, especially when traditional packaging is next to an unpackaged product, we may notice that attention is focused more on its presence than in your absence. The consumer seems to prefer the product inside the package when choosing a gift;

4) The message about family increases the probability of product choice by $9.2 \%$ : by analyzing the heat maps, the text with the suggestion of giving the family (although increasing the probability of product choice), ends up having less hot flashes than the others. This may be associated with Panettone's rapid understanding and gift-giving association with family (since brand communication is geared toward this positioning).

In this sense, analyzing the results, it can be concluded that:

H1: validated hypothesis;

$\mathrm{H} 2$ : hypothesis not validated;

H3a: not validated hypothesis;

$\mathrm{H} 3 \mathrm{~b}$ : validated hypothesis;

H4: validated hypothesis.

\section{REFERENCES}

Barreto, A. M. (2012). Eye tracking como método de investigação aplicado às ciências da comunicação. Revista Comunicando, 1(1), 168-186.

Batcho, K. I. (2007). Nostalgia and the emotional tone and content of song lyrics. The American Journal of Psychology, 361-381.

Belk, R. W. (1987). A child's Christmas in America: Santa Claus as deity, consumption as religion. Journal of American culture, 10(1), 87-100.

Belk, R. W. (1979). Gift-giving behavior. In. Research in Marketing. v.2, ed. Jagdish N. Sheth, Greenwich, CT: JAI Press, 95-126.

Boyle, M. (2009). "Sweet Brand of Youth.” Business Week, April.

França, D. B. D. (2019). Uma análise dos gastos e da propensão ao endividamento frente a datas comemorativas e temáticas.

Holak, S. L., \& Havlena, W. J. (1998). Feelings, fantasies, and memories: An examination of the emotional components of nostalgia. Journal of Business Research, 42(3), 217-226.

Klein, J. G., Lowrey, T. M., \& Otnes, C. C. (2015). Identity-based motivations and anticipated reckoning: Contributions to gift-giving theory from an identity-stripping context. Journal of Consumer Psychology, 25(3), 431-448.

Kotler, P. Administração de marketing: a edição do novo milênio. São Paulo: Prentice Hall, 2000. 
Oliveira, M. G. (2018). A influência do design na decisão de compra: um estudo de caso da embalagem do panetone santo grano.

Pépece, O. M. C. (2002). O ato de presentear: o único capaz de transmitir mensagens sem utilizar palavras, de expressar carinho sem utilizar o toque. In Congresso Brasileiro de Ciências da Comunicação (Vol. 25).

Pinto, M., \& Cruz, R. C. (2014). Experiências de consumo no Natal de cidades do interior de Minas Gerais. Gestão \& Regionalidade, 30(89), 35-48.

Santana, D. O., \& Ferreira, R. M. C. (2013). A verdadeira essência da felicidade e a publicidade natalina. In Anais do XII Congresso de Ciências da Comunicação na Região Norte. Sociedade Brasileira de Estudos Interdisciplinares da Comunicação (Intercom).

Schiffman, Leon G.; Kanuk, Leslie L. (2009). Comportamento do Consumidor. 9 ed. Rio de Janeiro: LTC Editora.

Taute, H. A., \& Sierra, J. J. (2015). An Examination of Emotional Information Management in Gift Giving and Receipt. Psychology \& Marketing, 32(2), 203-218.

Bodorik P. et al, 1991. Deciding to Correct Distributed Query Processing. In IEEE Transactions on Data and Knowledge Engineering, Vol. 4, No. 3, pp 253-265. 